Original Article

Received/Accepted

Dates

19.03.2021/12.04.2021

DOI

10.52096/jsrbs.6.1.7.13.7
Journal of Social Research and Behavioral Sciences

Sosyal Araştırmalar ve Davranış Bilimleri Dergisi

ISSN:2149-178X

Volume: 7 Issue: 13 Year: 2021

\title{
Ortaokul Öğretmenlerinin Görüşlerine Göre Ortaöğretim Merkezi Sınavı (LGS)’nin Üstünlükleri ve Sınırlıkları ${ }^{1}$
}

\section{Esra AZİi}

Sakarya Üniversitesi

Eğitim Bilimleri Enstitüsü

esraazili40@gmail.com

ORCID: 0000-0002-9477-7368

Prof. Dr. Ömer Faruk TUTKUN

Sakarya Üniversitesi

Eğitim Fakültesi

otutkun@sakarya.edu.tr

ORCID: 0000-0001-7973-0484

\section{Özet}

$\mathrm{Bu}$ araştırmanın amacı, ortaokul öğretmenlerine göre, 2017-2018 eğitim öğretim yılında uygulamaya konulan ortaöğretim merkezi sınavının üstün ve sınırlı yönlerini ortaya koymaktır. Araştırmanın çalışma grubunu, 2020-2021 eğitim-öğretim yılı ikinci dönemi, Ankara İli Mamak İlçesinde yer alan ortaokullarda görev yapan ve verilerin toplandığı dönem itibarıly 8. sınıflara derse girmiş olan toplam 47 öğretmen oluşturmuştur. Çalışmada, araştırma yöntemi olarak, nitel araştırma yöntemlerinden görüşme yöntemi uygulanmıştır. Araştırmada, veri toplama aracı olarak, yapılandırılmış görüşme formu kullanılmıştır. Araştırmada elde edilen veriler, betimsel analiz yöntemi ile analiz edilmiştir. Araştırmada elde edilen bulgular şunlardır: 1- Ortaokul öğretmenlerine göre, merkezi yerleştirme sınavının önceki lise giriş sınavlarına göre üstün yönü, en çok, sınavın ayırt ediciliğinin yüksek olması; sınırlı yönü ise üst düzey

\footnotetext{
${ }^{1}$ Bu çalışma, SAÜ Eğitim Bilimleri Enstitüsünde yapılan tezsiz yüksek lisans projesinden üretilmiştir. 9. Uluslararası Online Sosyal Araştırmalar ve Davranış Bilimleri Sempozyumu, 25-27 Haziran 2021, basılı olmayan sözlü bildiri olarak sunulmuştur.
} 
beceri gerektirmesidir. 2- Merkezi yerleştirme sınavının, başarılı/başarısız öğrenciyi ayırt edicilik özelliği, yalnızca evet şeklindeki sorularda yüksek, fakat üst düzey yetileri olan ve hızlı/pratik soru çözen öğrenciyi ayırt etmede yeterli değildir. 3- Merkezi yerleştirme sınavında öğrencilere sorulan beceri temelli soruların ortaokul öğretim programındaki kazanımlara göre, soruların zorlayıcıllğı uyumlu; fakat sorular üst düzey davranışları ölçme, uzunluğu, içerik anlaşılabilirliği ve ders kitapları ile örtüşmesi uyumlu değildir. 4Merkezi yerleştirme sınavının, ortaokul öğretim programında belirtilen ve geliştirmeyi hedeflediği temel becerileri ölçme düzeyi yeterlidir; fakat programda yer alan hedefler, üst düzey becerileri sorgulamada yeterli değildir. 5- Ortaokul öğretmenleri, çoğunlukla, uygulanan sistemde öğrencinin evinin yakınında okula gidecek olması ve sınav mecburiyetinin olmamasının, öğrenci başarısını etkileyeceği yönünde görüş belirtmişlerdir.

Anahtar Kelimeler: Merkezi yerleştirme sınavı, Sınav, Ortaokul, Lise, Öğrenci.

\title{
Advantages and Limitations of The Secondary Education Center Exam (SECE) According to The Opinions of Middle School Teachers
}

\begin{abstract}
The purpose of this research is to present the advantages and limitations of the Secondary Education Center Exam (SECE) conducted in 2017-2018 academic year in the opinions of middle school teachers. The study group of the research was consisted of 47 middle school teachers those who entered lessons the 8th grades as of the data collection period in Mamak district. As research method, semi-structured interview model, one of the qualitative research methods, was used in the study. As the data collection tool, structured interview form is applied. The data obtained from the interviews have been analyzed using the method of descriptive analysis. The findings obtained in the research are given below: 1- According to middle school teachers, the advantage of secondary education center exam as regards previous high school admission exams is high distinctiveness and limitation of SECE requires high-level skills. 2- The distinctiveness of successful/unsuccessful students of SECE is high when it comes to yes/no questions. However, it is not qualified to discern from students who is solving problems fast/practical and high level skilled. 3- In SECE, difficulty of skill-based questions is coherent with learning outcomes in secondary education curriculum. Nevertheless, they are not coherent with assessment of high-level behaviors, extent, content intelligibility and schoolbooks. 4- In SECE, assessment of basic skills stated and aimed to improve in secondary education curriculum is adequate. However, the aims in curriculum are not adequate to question high-level
\end{abstract}


skills. 5- According to middle school teachers, student achievement was affected by the students mostly register the closest school to their home and there is no obligation to have an exam.

Keywords: Central placement exam, Exam, Middle School, High school. Student.

\section{Giriş}

Ölçme ve değerlendirme, bir eğitim sisteminin ve eğitim programının en önemli bileşenlerinden birisidir. Ölçme ve değerlendirme ile bir yandan eğitim programının hedeflerine ne derecede ulaşıldığını, ulaşılmadı ise nedenlerini ortaya koyma ve bu çerçevede sistemi revize etme, diğer yandan, öğrenci başarı düzeyini belirleyerek, onun bir üst öğrenim kurumuna veya bir mesleğe yönlendirme ile ilgili karar verilir (Demirel, 2010; Sönmez, 2007; Turgut ve Baykul, 2013). Türkiye'de yerel ve merkezî olmak üzere öğrenci başarısı iki farklı şekilde değerlendirilmektedir. Yerel düzeydeki ölçme çalışmaları, öğrencilerin resmi eğitim aldıkları okullarda, öğretmenlerin yaptıkları ölçme-değerlendirilmeleri (Özdaş, 2019) ifade etmektedir. Merkezi değerlendirme ise, Milli Eğitim Bakanlığı (MEB) tarafından hazırlanan ve ulusal düzeyde gerçekleştirilen ölçmedeğerlendirme uygulamalarını (Çepni, Gökdere ve Özsevgeç, 2003) kapsamaktadır. Türkiye’de, orta öğretime öğrenci seçme sınavlarında, 1999 yılından 2018 yılına kadar beş defa değişiklik yapıldığı görülmektedir (Özdaş, 2019). Bunlar: 1993-2003 Liselere Giriş Sınavı (LGS), 20042006 Ortaöğretim Kurumları Seçme ve Yerleştirme Sınavı (OKS), 2007-2012 Seviye Belirleme Sınavı (SBS), 2013-2017 Temel Eğitimden Ortaöğretime Geçiş Sistemi (TEOG), 2018-... Liselere Geçiş Sistemi (LGS)'dir.

Günümüzde, öğrencilerin ilköğretimden ortaöğretime, yani Liseye geçişi için temel oluşturan ulusal düzeyde sınavlar, Milli Eğitim Bakanlığı tarafından uygulanmaktadır. Bu sınavların temel amacı, ortaokul mezunu öğrencileri, akademik başarılarına göre sıralayarak, seçili okul ya da programlara yerleştirmektir (Atilla ve Özeken, 2015; Büyüköztürk, 2016). Liselere geçiş sistemi (LGS) sınav1, ilk olarak 2018 yılında gerçekleştirilmiştir. Bu sınav, resmî ve özel ortaokullar, imam hatip ortaokulları ve geçici eğitim merkezlerinin 8.sınıflarında öğrenim gören öğrencilerin, Fen Liseleri, Sosyal Bilimler Liseleri, Özel Program ve Proje Uygulayan Eğitim Kurumları, Mesleki ve Teknik Anadolu Liselerinin Anadolu Teknik Programlarına kayıt olabilmeleri için Milli Eğitim Bakanlığı tarafından tüm Türkiye'de merkezi olarak yapılmaktadır (MEB, 2018a). 
Türk eğitimin sisteminin en önemli köşe taşlarından birini oluşturan liseye geçiş sınavları, 19992018 yılları arasında beş defa değiştirilmek zorunda kalınmıştır. Bu zorunluluğu oluşturan sebepler şöyle sıralanabilir: sınavın niteliğini daha iyi ve kapsamlı duruma getirme; bölgeler arası eğitim uygulamalarında belirgin farklılıkları ortadan kaldırma; öğrencilerin yaşadığı yoğun sınav stresini azaltma; sosyal ve ekonomik değişimler; eğitimin paydaşlarının -siyasal, toplumsal- talep ve beklentileri; bilim, teknoloji, anlayış değişimleri ve yenilikleri; hızlı nüfus artışı ve dolayısıyla mevcut sistemin ihtiyaca cevap verememesi (Görmez ve Coşkun, 2015; Gür, Çelik ve Coşkun, 2013; Özdaş, 2019; Özkan ve Karataş, 2016). Fakat bu faktörlerin yanı sıra, yapılan sınav değişikliklerinin temel sebebi olarak, yalnızca bilgiyi alan değil, bilgiyi alıp, üst düzey yetileri ile yeniden yapılandırabilen ve üretken bireyler yetiştirilmesinin hedeflenmesi gösterilebilir. Tüm bu etkenler, eğitim sisteminde, bilgi ve kavrama düzeyindeki hedeflere ulaşma ile sınırlı kalan öğretme-öğrenme süreçleri ve ölçme ve değerlendirme yerine, öğrenmeyi öğrenme ve uygulama anlayışını beraberinde getirmekte, böylece, bir üst öğretim kurumlarına giriş sınavlarının biçim ve içeriğinin değişimine sebep olmaktadır. Diğer yandan, dünyada, eğitim alanında yapılan ulusal değerlendirme çalışmalarının yanı sıra, uluslararası düzeyde de ülkelerin eğitim alanında konumunu belirlemek amacıyla eğitim göstergelerine gereksinim duyulmaktadır. Nitekim Türkiye de, Ekonomik İşbirliği ve Kalkınma Örgütü (OECD) üyesi olarak, eğitim seviyesini uluslararası genel sıralamada üst kademelere taşımayı hedef edinerek uluslararası araştırmalara dâhil olmaktadır. PİSA (Uluslararası Öğrenci Değerlendirme Programı) ve TIMMS (Uluslararası Matematik ve Fen Eğilimleri Araştırması) bu uygulamaların başında gelmektedir (MEB, 2018b).

Her açık sistemde olduğu üzere, eğitim sisteminin de girdi-işlem-çıktı ve dönüt mekanizması mevcuttur (Sönmez, 2007; Ertük, 2017; Turgut ve Baykul, 2014). Eğitim sisteminin başlıca dönütü sınavlar aracılığı ile sağlanabilir. Bu bağlamda, sınavsız bir eğitim sistemi düşünülemez. Sınavlar, özellikle eğitim sisteminin sonuçlarına ilişkin olmak üzere, öğrencilere, aileye, okula, topluma, karar vericilere ve bilim insanlarına, eğitimin her bir öğesine ilişkin dönüt -bilgi- veren en önemli ölçme araçlarıdır. Özellikle ulusal çapta yapılan ve toplumsal düzeyde büyük etkiye sahip olan lise giriş sınavlarının organizasyonu, uygulaması, sonuçları ve değerlendirilmesinde en önemli paydaşlardan birisi öğretmenlerdir. Bu nedenle, öğretmenlerin uygulanmakta olan sınav sistemine ilişkin görüşlerinin ve önerilerinin dikkate alınmasının, genelde program geliştirme ve değerlendirme süreçlerinde, özelde, lise giriş sınavlarının işlevselliğini değerlendirme açısından çok değerli katkılar sağlayacağı söylenebilir. Çünkü eğitim-öğretim süreci içerisinde yer alan ve 
uygulayıcısı olan öğretmenlerin, öğrencilerin yeterlikleri hakkında en gerçekçi ve kapsamlı bilgiye sahip grup olduğu söylenebilir ((Büyüköztürk, 2016; Cüceloğlu ve Erdoğan, 2018).

Bu çalışmanın amacı, Türkiye'de, 2017-2018 eğitim-öğretim yılında uygulamaya konulan merkezi yerleştirme sınavının güçlü ve zayıf yönlerini, ortaokul öğretmenlerinin görüşlerine göre ortaya koymaktır. $\mathrm{Bu}$ ana araştırma problemi doğrultusunda, araştırma soruları şunlardır: Ortaokul öğretmenlerine göre, 1- Merkezi yerleştirme sınavın önceki lise giriş sınavlarına göre üstün ve sınırlı yönleri nelerdir? 2- Merkezi yerleştirme sınavı, başarılı öğrenci ile başarısız öğrenciyi birbirinden ayırt edebilmekte midir? 3- Merkezi yerleştirme sınavında yer verilen beceri temelli sorular, ortaokul öğretim programındaki kazanımlara uygun mudur? 4- Merkezi yerleştirme sınavı, ortaokul öğretim programının hedeflediği temel becerileri -problem çözme, eleştirel düşünme, yaratıcı düşünme, karar verme, değişim ve sürekliliği anlama, sosyal katılım, akıl yürütme gibiölçmede yeterli midir? 5- Liselere geçiş sisteminde, öğrencilerin evinin yakınında okula gidecek olması ve sınav mecburiyetinin olmaması öğrenci başarısını etkilemekte midir? Çalışma bulgularının, başta ulusal düzeyde yapılan sınavların düzenlenmesi ve uygulamasındaki karar vericilere, öğretmenlere, velilere ve tüm kamuoyuna katkı sağlayıcı düşünülmektedir.

\section{Yöntem}

Bu çalışmada araştırıma yöntemi olarak, nitel araştırma yöntemi ve yapılandırılmış görüşme tekniği kullanılmıştır. Araştırmanın çalışma grubunu, 2020-2021 eğitim-öğretim yılı ikinci döneminde, Ankara İli Mamak İlçesindeki ortaokullarda görev yapan ve verilerin toplandığı dönem itibarıyla 8. sınıflara derse girmiş olan toplam 47 öğretmen oluşturmuştur. Araştırmanın çalışma grubuna kolay ulaşılabilir örnekleme yöntemi ile ulaşılmıştır. Çalışma grubunu oluşturan öğretmenlerin 29'u kadın, 18'i erkek öğretmendir. Araştırmada veri toplama aracı olarak, araştırmacı tarafından hazırlanan ve 5 adet açık uçlu sorudan oluşan yapılandırılmış görüşme formu kullanılmıştır. Görüşme formu, yaşanan salgın hastalık nedeniyle, öğretmenlere çevrim içi ve internet tabanlı bazı mesajlaşma uygulamalarından yararlanılarak uygulanmıştır. Elde edilen verilerin çözümlenmesinde betimsel analiz yöntemi kullanılmıştır (Yıldırım ve Şimşek, 2013). 


\section{Bulgular}

1- Ortaokul öğretmenlerine göre, merkezi yerleștirme sınavın önceki lise giriş sınavlarına göre üstün ve sınırlı yönlerine dair ait bulgular:

Tablo 1'e göre, öğretmenler, soruların ayırt edicilik yönünün belirgin olmasını $(\% 46,7)$, sınavın senede bir uygulanmasını $(\% 26,7)$, soruların sadece 8 .sınıf müfredatını kapsar olmasını $(\% 13,3)$, üç yanlışın bir doğruyu götürmesini $(\% 6,7)$ ve üst düzey beceri gösteren öğrencinin başarılı sayılmasını $(\% 6,7)$ LGS sınavının üstün yanları olarak belirtmişlerdir. Ayrıca, sınavda 3 yanlışın 1 doğruyu götürmesi ve sınavın üst düzey beceri gösteren öğrencileri aktif kılması farklı tema altında ifade edilen kodlar olup, bu tema altında frekans dağılımının eşit olduğu görülmektedir. Soruların ayırt edicilik yönünün belirgin çalıştığına dair bulunan ifadeler ( $f=7)$ ise LGS'nin üstün yanını ifade eden bulgular arasında frekans dağılımı açısından diğer bulgulara göre daha sıklıkla görülmüştür.

Tablo 1. 2018 Yılında Uygulamaya Konulan Merkezi Yerleştirme Sınavın (LGS) Önceki Lise Giriş Sınavlarına Göre Üstün Yönlerine Dair Öğretmen Görüşleri

\begin{tabular}{lllc}
\hline Temalar & Kod & Katılımcı & Frekans \\
\hline Sınavın & 3 yanlışın 1 doğruyu & Ö31 & 1 \\
\cline { 2 - 4 } uygulanmasına & Soruların sadece 8.sınıf & Ö22,Ö46 & 2 \\
yönelik & Siñavınıtın bir defa uygulanıyor & Ö21,Ö22,Ö33,Ö37 & 4 \\
\hline \multirow{2}{*}{ İceriğe dönük } & Soruların ayırt edicilik & Ö1,Ö7,Ö8,Ö25,Ö27,Ö & 7 \\
\cline { 2 - 4 } & Üst düzey beceri gösteren & Ö2 & 1
\end{tabular}

Tablo 1'deki tema ve kodlardaki frekans yı̆̆ılmaları Grafik 1'de yer almaktadır. 


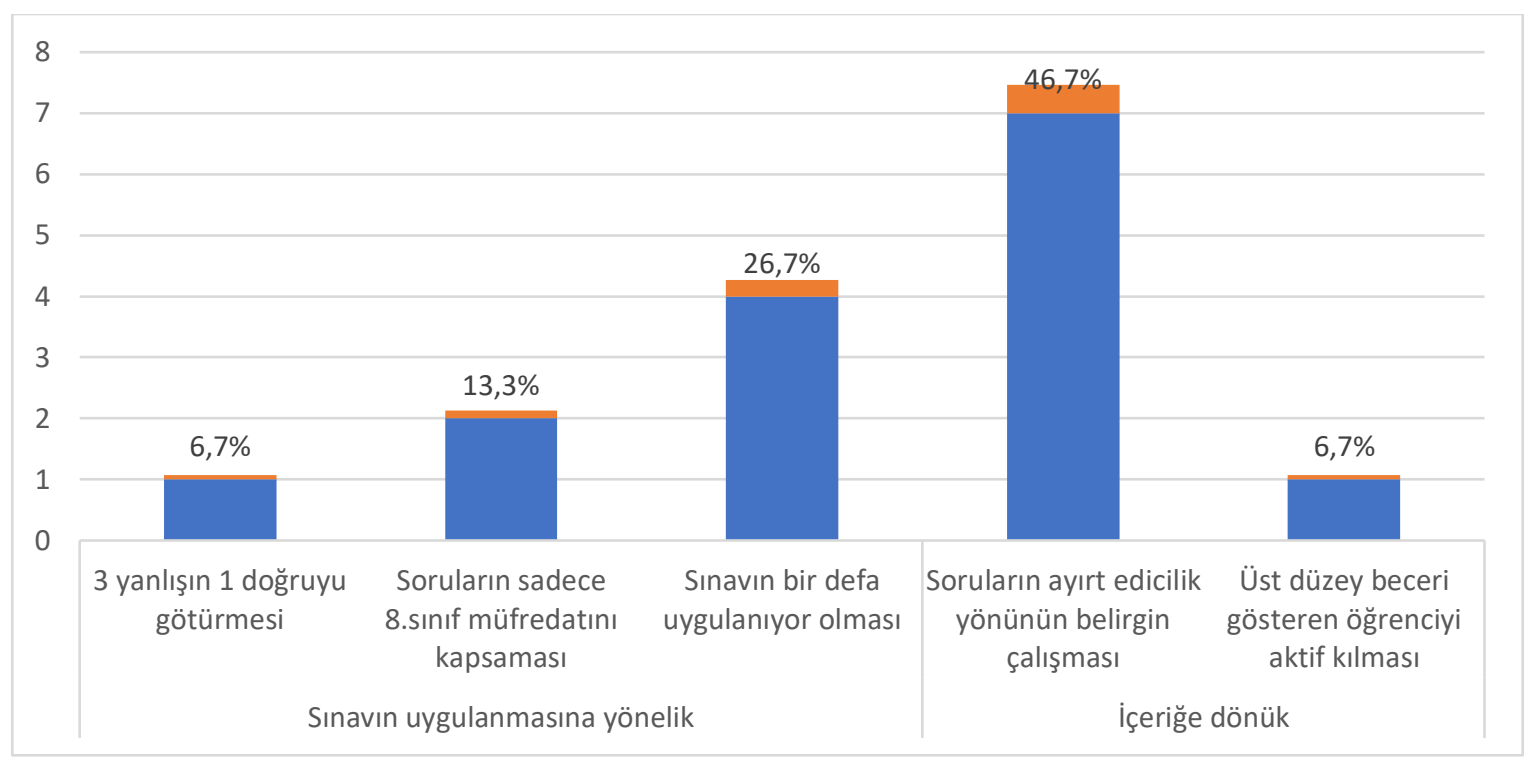

Grafik 1. 2018 yılında uygulamaya konulan merkezi yerleştirme sınavın (LGS) önceki lise giriş sinavlarına göre üstün yönlerine dair öğretmen görüşleri

Üstün yanlarının ifade edildiği birebir öğretmen yanıtlarından bazı örnekler şöyledir.

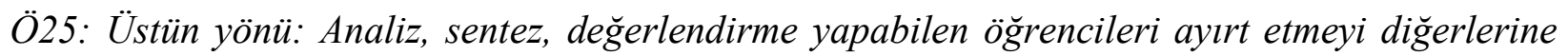
göre daha iyi yapıyor.

Ö46: Üstün yönü tek bir sınıf seviyesinden yani sadece 8. Sınıf konularından çıkmasıdır. Bu da çocuklarda ki hazırlık aşamasını ve stres düzeyini düşürmektedir. Sınırl yönleri ise okulları nitelikli veya niteliksiz şeklinde ayırmış olmaları. Bunun sonucunda da nitelikli okulların kontenjanlarl az olduğundan yüzde on haricindeki öğrenciler için lise eğitim kalitesinin düşmüş olmasıdır.

Ö8: Düzenli çalışan ögrencileri ayırt edebilmesi.

Ö7: Üstün yönü daha seçici olmast.

Ö30: Üstün yönleri: Ayırt edicilik faktörünün işlevsel çalışmast.

Ö31: Üstün yönü: Sınavda 3 yanlışın 1 doğruyu götürmesi başarılı olan öğrenciyi ön plana çıkarlyor.

Ö33: Üstün yönü çocuklar 1 kere sinav stresi yaşıyor. 
Tablo 2. 2018 Yılında Uygulamaya Konulan Merkezi Yerleştirme Sınavının (LGS) Önceki Lise Giriş Sınavlarına Göre Sınırlı Yönlerine Dair Öğretmen Görüşleri

\begin{tabular}{|c|c|c|c|}
\hline Temalar & Kod & Katılımcı & Frekan \\
\hline \multirow{2}{*}{$\begin{array}{l}\text { Sinavın } \\
\text { uygulanmasına } \\
\text { yönelik }\end{array}$} & Sınavın her öğrenciye hitap & Ö12,Ö13,Ö15,Ö17,Ö36 & 5 \\
\hline & Eğitim döneminin sonunda & Ö21,Ö22,Ö37,Ö38 & 4 \\
\hline \multirow{5}{*}{ İçerik } & Soruların müfredat kapsam1 & Ö2,Ö22,Ö45 & 3 \\
\hline & Soruların uzun, zor olması & Ö9,Ö10,Ö19,Ö31,Ö41 & 5 \\
\hline & 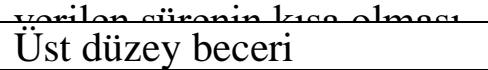 & Ö1,Ö4,Ö11,Ö12,Ö13,Ö & 7 \\
\hline & Sorular arasında katsayı & Ö1,Ö33,Ö37,Ö38, Ö44 & 5 \\
\hline & Yeni nesil soruları & Ö3,Ö5,Ö16,Ö47 & 4 \\
\hline \multirow{3}{*}{$\begin{array}{l}\text { Duyuşsal } \\
\text { anlaman }\end{array}$} & $\begin{array}{l}\text { anlomolyto ciinliil } \\
\text { Sinav kayg1S1 }\end{array}$ & Ö5 & 1 \\
\hline & Güdülenmedeki yetersizlik & Ö4 & 1 \\
\hline & Üst düzey öğrencilerin & Ö1,Ö2,Ö13 & 3 \\
\hline \multirow{2}{*}{$\begin{array}{l}\text { Değerlendirmeye } \\
\text { yönelik }\end{array}$} & $\begin{array}{l}\text { Lanomed anarlmana } \\
\text { Senede bir defada }\end{array}$ & Ö19,Ö21,Ö22,Ö31,Ö33 & 5 \\
\hline & $\begin{array}{l}\text { Her ögrencinin sınava } \\
\text { katılma hakkının olması }\end{array}$ & Ö29,Ö36,Ö43,Ö45,Ö46 & 5 \\
\hline
\end{tabular}

Tablo 2'deki tema ve kodlardaki frekans yı̆̆ılmaları Grafik 2'de yer almaktadır. 


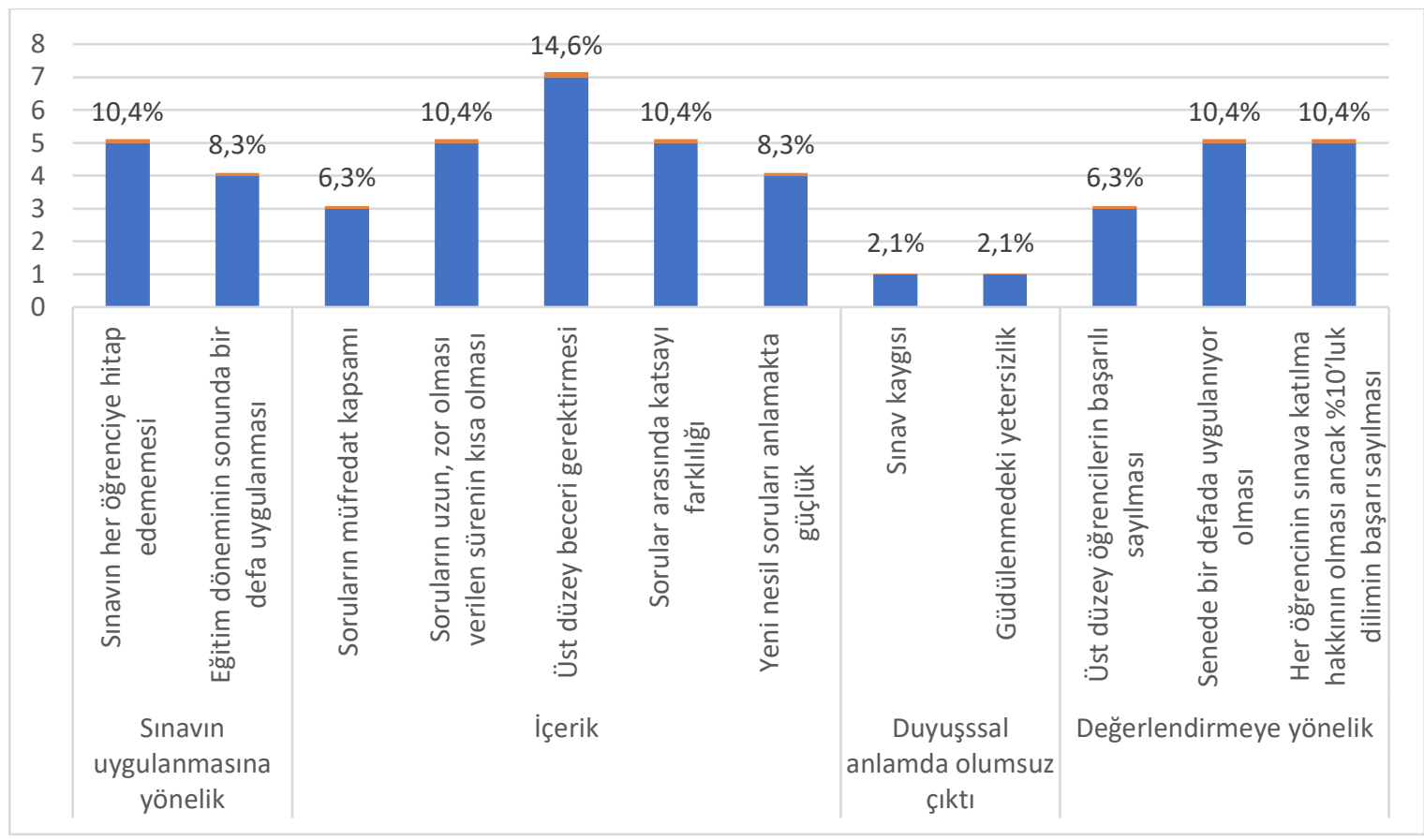

Grafik 2. 2018 yılında uygulamaya konulan merkezi yerleştirme sınavın (LGS) önceki lise giriş sınavlarına göre sınırlı yönlerine dair öğretmen görüşleri

Tablo 2'ye göre, öğretmenler, LGS sınavının sınırlı yanları olarak; soruların oldukça uzun ve zor olmasını $(\% 10,4)$, soruların üst düzey beceri gerektirmesini $(\% 14,6)$ ve bu sebeple öğrencilerin yeni nesil soruları anlamakta güçlük yaşamasını $(\% 8,3)$, sorular arasında katsayı farklılığının $(\% 10,4)$ olmasını ifade etmişlerdir. İçerik temasında, öğretmen ifadelerinin \%10.4 diliminde, sorular arası katsayı farklılığı ile soruların uzun ve zor olması belirtilirken; \%14,6'lık diliminde ise, soruların üst düzey beceri gerektirmesi ifade edilmiştir. Sınavın uygulanmasına yönelik oluşturulan temada, \%10,4'lük dilimde alınan yanıtlar sınav sorularının zor ve uzun olduğu, soruların her öğrenciye hitap edemediği ve soruları cevaplama süresinin yetersiz olduğu şeklindedir. Aynı zamanda, \%8,3'lük bir dilimde öğretmenler, sınavın senede bir defada uygulamaya yönelik olmasını olumsuzluk olarak ifade etmişlerdir. Değerlendirme teması altında, \%10’luk bir dilimin başarılı sayıldığı bir sınavda, "her öğrencinin sınava katılma hakkının olması” yanıtı, \%10,4'lük frekans yığılımı göstermiştir. Duyuşsal boyutta, sınava karşı olumsuz tutum, sınav kaygısı, güdülenmedeki yetersizlik gibi sebepler olumsuzluk olarak ifade edilmiştir (\%2,1). Öz olarak, LGS sınavının önceki sınav ve sürece kıyasla zayıf yönlerine ilişkin öğretmen yanıtları incelendiğinde, 4 ana temaya ulaşılmıştır. Bunlar; içeriğe dönük, sınavın uygulanmasına yönelik, 
duyuşsal olarak olumsuz çıktılar ve değerlendirme aşamasına yönelik eksikliklerdir. İçeriğe dönük, sınavın uygulanması, duyuşsal ve değerlendirme temalarında en sık tekrar eden kodlara ait birebir örnek öğretmen yanıtları şu şekildedir.

Ö4: Okuduğunu anlamaya yönelik bir sinav. Öğrencilerin kitap okuma ve paragraf sorusu çözme alışkanlığının olması gerekiyor. Yalnız bazı öğrenciler çok zorlandı̆̆ iç̧in ümitsizliğe kapılıp sinava çalışmayı birakıyorlar. Özellikle matematik dersinde zorlaniyorlar.

Ö25: Üstün yönü: Analiz, sentez, değerlendirme yapabilen öğrencileri aylrt etmeyi diğerlerine göre daha iyi yaplyor. Sinırl yönü, öğrencilerin bu sinava yönelik ön öğrenmelerinin eksik olmasl, müfredat ve sistem yapısının bu sinav şartlarında soru, yöntem ve teknik ögretmiyor olması sebebiyle öğrencilerin çabuk pes etmesine neden oluyor.

Ö46: Üstün yönü, tek bir sinıf seviyesinden yani sadece 8. sinıf konularından çıkmasıdır. Bu da çocuklarda ki hazırlık aşamasını ve stres düzeyini düşürmektedir. Sinırl yönleri ise okullarl nitelikli veya niteliksiz şeklinde ayırmış olmaları. Bunun sonucunda da nitelikli okulların kontenjanları az olduğundan, yüzde on haricindeki öğrenciler için lise eğitim kalitesinin düşmüş olmasidir.

Ö12: Üst düzey sorular soruluyor olmasl güzel fakat bu belli bir saylda olmalı. 20 sorunun hepsi yeni nesil olunca, orta ve alt düzey ögrenci çalışmayı bırakıyor. Bu nedenle, LGS'nin değişmesini her ögrenci seviyesine uygun sorulardan oluşmasını arzu ediyorum.

Ö38: Tek sinav olması güzel, fakat, sinavda sorulan branş derslerindeki kat sayı fark çok çok fazla. Bu da dersler arasında ögrencileri çelişkiye sokuyor. Sanki kat saylsı az olan dersler önemsiz, diğerleri daha önemli gibi. Çünkü 1 e 4 büyük bir oran.

Ö45: Sinavın üstün başarılı öğrenciyi tespit etmeye yönelik bir amacı var. Ancak nitelikli okul sayısı belirlenen eğitim bölgeleri içinde sayıca az. Tüm öğrencilerin sinava girmeye teşvik edilmesi okul başarı ortalamalarını düşürüyor.

Ö33:Üstün yönü çocuklar 1 kere sinav stresi yaşlyor sinırll yönü ise puan türünde din kültürü inkılap tarihi ve İngilizce derslerinin kat sayılarının matematik Türkçe fen bilimlerinden çok düşük olması çocukların kat sayısı düşük derslere yönelmemesine sebep oluyor. 
Ö17: Üstün yönü olduğunu düşünmüyorum. TEOG yapıldığı dönemde kırsal kesimden birçok ögrencinin iyi okullara gidebildiğini görürken LGS ile sadece iyi imkânları olan şehirlerde yasayan ögrencilerin kaliteli okullara gidebildiği görülmektedir. İstisnalar hariç.

2- Ortaokul öğretmenlerine göre, merkezi yerleştirme sınavının başarılı öğrenci ile başarısız öğrenciyi birbirinden ayırt edebilmesine dair bulgular:

Tablo 3'e göre, yeterli teması altında, yalnızca evet (\%50), LGS'nin daha çok üst düzey yetilerde kendini gösterebilen öğrenciyi seçtiği (\%10,7), hızlı pratik ve çok soru çözen öğrencileri ayıt ettiği $(\% 3,6)$, ifade edilmiştir. Yeterli değil teması altında ise; yalnızca hayır $(\% 14,3)$, üst düzey yetilerde kendini gösterebilen öğrenciyi seçtiği (\%10,7), hızlı pratik ve çok soru çözen öğrencileri ayırt ettiği $(\% 10,7)$ ifade edilmiştir.

Tablo 3. Öğretmenlerin Merkezi Yerleştirme Sınavının Ayırt Ediciliği Hakkında Görüşleri

\begin{tabular}{|c|c|c|c|}
\hline Tema & Kod & Katılımeı & Frekan \\
\hline \multirow{4}{*}{ Yeterli } & Yalnızca evet şeklindeki & Ö1,Ö4,Ö11,Ö14,Ö22,Ö24, & 14 \\
\hline & & م̈2 & \\
\hline & Üst düzey yetileri olan & Ö13,Ö15,Ö18 & 3 \\
\hline & Hizlı ve pratik olan çok soru & Ö3 & 1 \\
\hline \multirow{3}{*}{$\begin{array}{l}\text { Yeterli } \\
\text { değil }\end{array}$} & 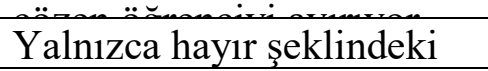 & Ö6,Ö12,Ö35,Ö39 & 4 \\
\hline & Üst düzey yetileri olan & Ö3,Ö18,Ö21 & 3 \\
\hline & Hizlı ve pratik olan çok soru & Ö47,Ö16,Ö47 & 3 \\
\hline
\end{tabular}

Tablo 3'deki tema ve kodlardaki frekans yığılmaları Grafik 3'de yer almaktadır. 


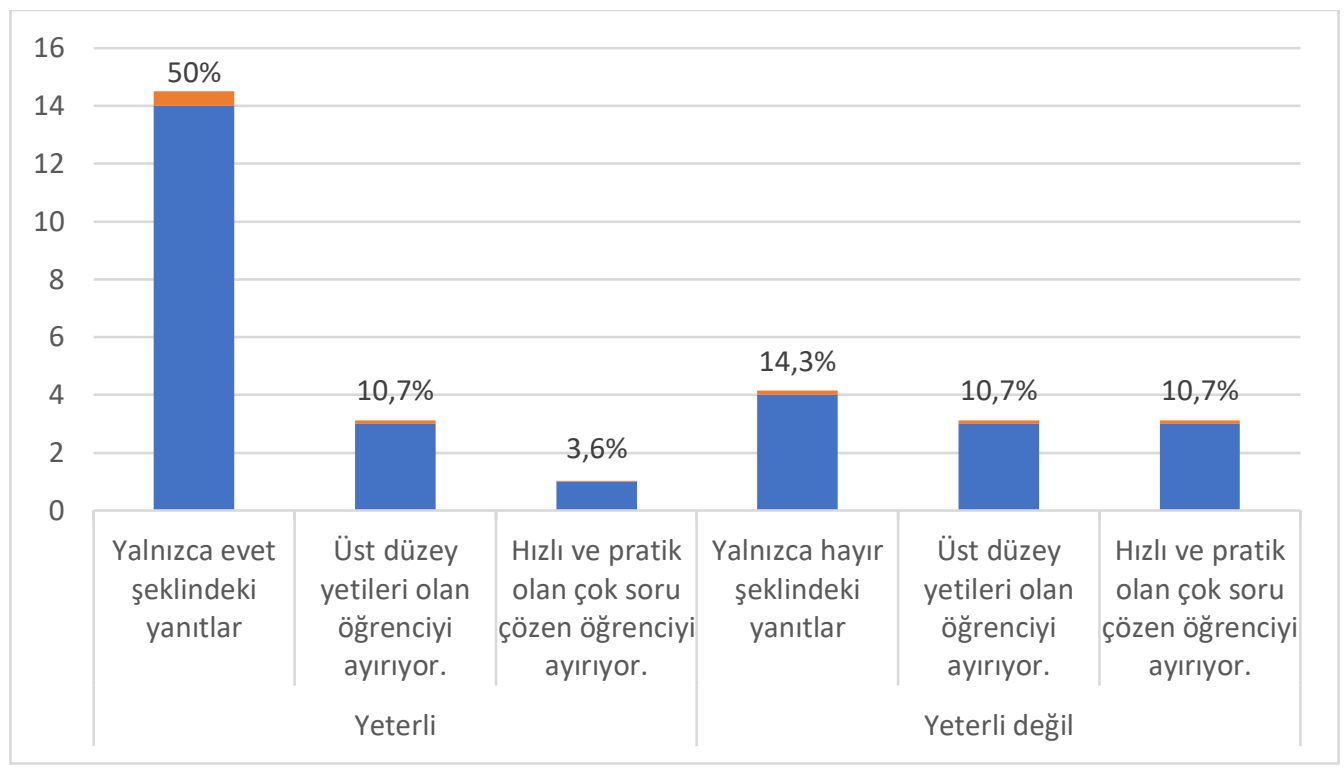

Grafik 3. Öğretmenlerin LGS'nin ayırt ediciliği hakkında görüşleri

Burada dikkat çeken detay, farklı temalarda aynı kodların oluşturulmasıdır. Alınan yanıtlarda, şaşırtıcı durum ise aynı ifadeler ile farklı temaların temsil ediliyor olmasıdır. Aşağıda verilen birebir öğretmen yanıtları bu durumu destekler niteliktedir.

Ö3: Hayır, LGS daha ileri düzeyde bir yoklama yapıyor. Temel düzeyde değil. Yani öğrenci konuyu bilecek, analitik düşünecek, okuduğunu anlayan düzeyde ögrencilerin yarışı şeklinde

Ö13: Evet, zeki ve çok çalışanları ayırt edebiliyor.

Bunun yanı sıra, nitelikli okullarda öğrenim gören öğrenciyi başarılı kılan bir sistemde, sınav heyecanı ve benzeri gibi sebeplerden ötürü sınava yenik düşen başarılı bir öğrencinin, nitelikli okulda öğrenim görememesinin sınavın ayırt ediciliğini olumsuz yönde etkilediği belirtilmektedir. Yine, sınavın sayısal alanda oldukça zor sorular içermesi, sözel alanda ise kapsam geçerliliğinin yetersiz olarak belirtilmesi, soruların paragraf çözmeye yönelik olması bilginin öğrenilmesinden ziyade doğrudan yoruma açık hale getirilmesi sınavın ayırt ediciliğini düşürdüğü, başarılı ve başarısız öğrenciyi seçmede engel oluşturduğu öğretmenler tarafindan verilen yanıtlar arasındadır. Aşağıda, LGS'nin ayırt ediciliğini ifade eden birebir öğretmen yanıtları yer almaktadır.

Ö29: Sorular oldukça zor, okulda başarılı olduğu halde nitelikli okullara yerleşemeyen çok ögrenci olabiliyor.

Ö17: Matematik gibi zor soruların olduğu bir derste ayırt edebiliyor. Ama sosyal gibi, din gibi, Ingilizce gibi katsayısı düşük derslerde bu ayırt etmeyi sağlayamıyor. 
Ö23:Mantık muhakeme sorulart LGS'de ön planda. Eski sistem biraz daha ezbere dayallydl. LGS'de sözel yetenekli ögrenciler için dezavantajlı bir durum söz konusu. LGS'de sözel soruları biraz daha zorlaştırılarak, sözeli iyi olan ögrenciler biraz daha avantajlı duruma getirilebilir.

3- Ortaokul öğretmenlerine göre, merkezi yerleştirme sınavında öğrencilere sorulan beceri temelli soruların ortaokul öğretim programındaki kazanımlara uygunluğuna dair bulgular:

Tablo 4. Öğretmenlerin LGS'de Öğrencilere Sorulan Beceri Temelli Soruların Ortaokul Öğretim Programındaki Kazanımlara Uygunluğu Hakkındaki Görüşleri

\begin{tabular}{|c|c|c|c|}
\hline Tema & Kod & Katılımcılar & Frekans \\
\hline \multirow{3}{*}{ Uyumlu } & Kazanım sorularına göre & Ö1,Ö29,25,Ö27,Ö33 & 5 \\
\hline & Kazanım sorularına göre & Ö5,Ö17 & 2 \\
\hline & $\begin{array}{l}\text { Soruların üst düzey } \\
\text { davranışları ölçmesi ve ders }\end{array}$ & Ö5,Ö12,Ö22,Ö31,Ö36,Ö22 & 6 \\
\hline \multirow{3}{*}{$\begin{array}{l}\text { Uyumlu } \\
\text { değil }\end{array}$} & Soruların uzun ve içerik & Ö18,Ö39,Ö45,Ö46,Ö10,Ö18 & 6 \\
\hline & $\begin{array}{l}\text { holımındon anlacilır } \\
\text { Soruların ders içi }\end{array}$ & Ö2,Ö4,Ö5,Ö40,Ö41 & 5 \\
\hline & 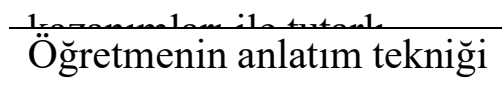 & Ö1,Ö35 & 2 \\
\hline
\end{tabular}

Tablo 4'deki tema ve kodlardaki frekans yığılmaları Grafik 4'de yer almaktadır. 


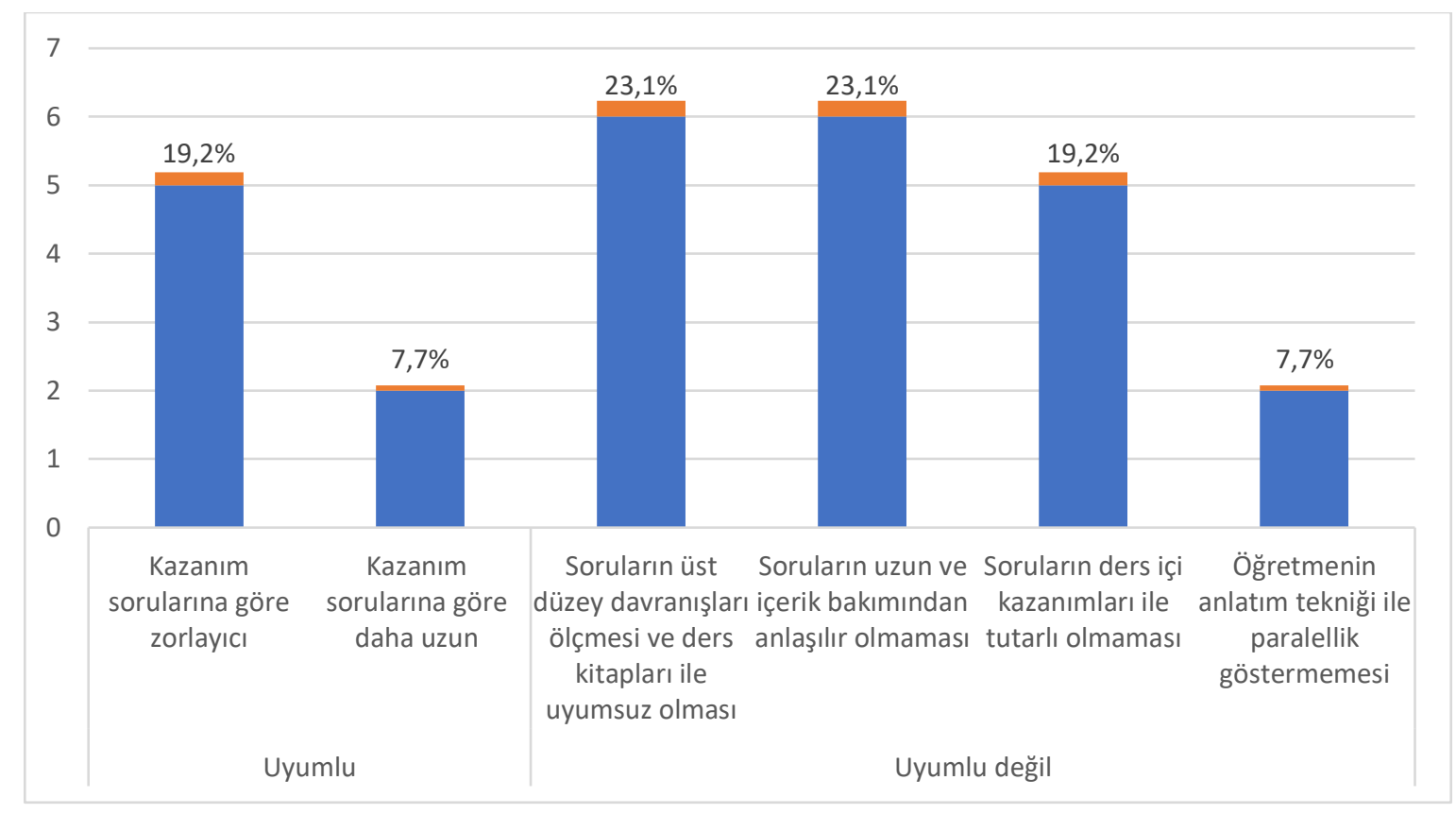

Grafik 4. Öğretmenlerin LGS'de öğrencilere sorulan beceri temelli soruların ortaokul öğretim programındaki kazanımlara uygunluğu hakkındaki görüşleri.

Tablo 4'e göre, öğretmenlerin LGS'de öğrencilere sorulan beceri temelli soruların ortaokul öğretim programındaki kazanımlara uygunluğu hakkındaki görüşleri, “uyumlu değil” teması altında (\%73) yoğunlaşmaktadır. Uyumlu değil teması altında, LGS'de sorulan beceri temelli soruların, üst düzey davranışları ölçmesi ve ders kitapları ile uyumsuz olması $(\% 23,1)$, soruların uzun ve içerik bakımından uzun ve anlaşı1ır olmaması $(\% 23,1)$, soruların ders içi kazanımlar ile tutarlı olmaması $(\% 19,2)$ ve beceri temelli soruların öğretmenlerin anlatım teknikleri ile paralellik göstermemesi $(\% 7,7)$ ifade edilmiştir.

Uyumludur teması altında, kazanım sorularına göre zor olduğu $(\% 19,2)$ ve kazanım sorularına göre uzun olduğu $(\% 7,7)$ ifade edilmiştir. Bu duruma ilişkin bazı birebir öğretmen yanıtları şöyledir:

Ö5: Kazanımlar çok daha kolay, ders kitaplarındaki anlatım çok kısıtll. Tema Değerlendirme Soruları da sinav sorularına göre çok basit.

Ö18: Beceri temelli bazı sorular, kazanımların çok ilerisinde zorlayıcı sorular. 
Ö39: Yeni nesil soru adında gereksiz uzatılmış, bilgi ölçmeden çok dikkat dağıtmayı amaçlayan soru tiplerinden vaz geçilmeli.

Bu başlık altında, bir kısım öğretmenler, LGS sorularının kazanımlar ile uyumsuzluğunu sorular üzerinden değerlendirirken, diğerleri de, bu uyumsuzluğu kazanımlar üzerinden değerlendirmişlerdir. Şöyle ki; ifadeleri soruların uzun ve yoğun anlam içerikli eleştirel ve muhakeme gücü yüksek olduğunu destekler nitelikte, ancak, kazanımların okuma anlama ve ifade becerisini kazandırmada yetersiz olduğunu belirtmişlerdir. $\mathrm{Bu}$ duruma ilişkin bazı birebir öğretmen yanıtları şöyledir:

Ö12: Mantık-muhakeme yönü güçlü, okuduğunu hemen anlayan çocuklarımız, konuyu da anladıysa rahatlıkla üstesinden gelebiliyor. Fakat okuduğunu anlama, kitap okuma alışkanlığı ile ilgilidir ve bu alışkanlık küçük yaşlarda kazanılan bir davranıştır. Ne yazık ki başarılı çocuklarımızda süreden kaybediyor. Okuduğunu anlayana kadar zaman geçiyor.

Ö40: Ders kitapları ile uyumlu değil, ders kitapları bu yönde gelişstirilmeli

LGS sınav sorularının kazanımlar ile uyumlu olduğunu belirten yanıtların, daha fazla öğretmen yeterliliğini ve öğretmeye ayrılan zamanı eleştiriyor olması, dikkat çeken bir husustur.

Ö1:Genel olarak uygun, fakat bazen gerçekten çok yönlü düşünüp fazlaca yorum katmanız gerekiyor. Ama biz öğretmenler, bu kadarını okulda veremiyoruz vakit kısıtlı olduğundan

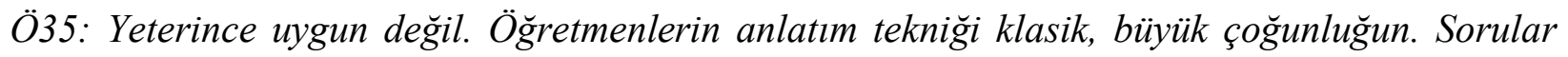
uygulama. Çatışma oluşturuyor. Öğretmen dönüşümüne ihtiyaç var.

\section{4- Ortaokul öğretmenlerinin, merkezi yerleştirme sınavının, ortaokul öğretim programında hedeflenen temel becerileri -problem çözme, eleştirel düşünme, yaratıcı düşünme, karar verme, değişim ve sürekliliği anlama, sosyal katılım, akıl yürütme gibi- ölçme yeterliliği hakkındaki görüşlerine dair bulgular:}

Tablo 5'e göre, öğretmenlerin ortaokul öğretim programında belirtilen ve geliştirmeyi hedeflediği temel becerileri merkezi yerleştirme sınavının ölçmedeki yeterliliğine dair görüşlerinin yaklaşık \%58'lik kısmının yeterli değil teması altında toplandığı ve oluşturulan kodların daha çok 
sistemdeki eksiklikleri referans gösterir nitelikte olduğu görülmektedir. Yeterli değil teması altında ifade edilen görüşler şu şekildedir: Kazanım ile soru türlerinin uyuşmaması $(\% 15,4)$, kazanımların verilen eğitimle örtüşmemesi $(\% 15,4)$, kullanılan kaynakların öğrenciyi muhakeme becerisini sunmadaki yetersizliği $(\% 3,8)$, üst düzey becerileri ölçen bir sınavın hazırlık aşamasının aşamalı ve temelden başlayarak olması gerektiği ve bu duruma aynı zamanda öğretmenlere de hizmet içi eğitimler destek programları hazırlanması gerektiği $(\% 7,7)$, programda belirtilen hedeflerin üst düzey becerileri sorgulamadan uzak olması ve ayrıca üst düzey becerilerin ifade edildiği bir sınavın çoktan seçmeli olarak yapılması $(\% 15,4)$.

Öğretmen görüşlerinin yaklaşık \%42'lik diliminde ise, LGS'nin ortaokul öğretim programında belirtilen ve geliştirmeyi hedeflediği temel becerileri ölçmede yeterli olduğu ifade edilmiştir.

Tablo 5. Öğretmenlerin LGS'nin, Ortaokul Öğretim Programında Belirtilen ve Geliştirmeyi Hedeflediği Temel Becerileri Ölçmedeki Yeterliliği Hakkındaki Görüşleri

\begin{tabular}{|c|c|c|c|}
\hline Tema & Kod & Katılımcilar & Frekans \\
\hline Yeterli & Yalnızca evet ya da yeterli şeklindeki & Ö1,Ö2,Ö4,Ö5,Ö10, & 11 \\
\hline \multirow{7}{*}{$\begin{array}{l}\text { Yeterli } \\
\text { Değil }\end{array}$} & Kazanimim ile soru türlerinin & 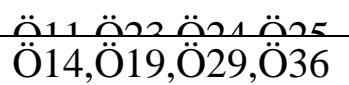 & 4 \\
\hline & Kazanımların verilen eğitimle & Ö18,Ö22,Ö27,Ö43 & 4 \\
\hline & Kullanılan kaynakların öğrenciyi & Ö18 & 1 \\
\hline & Üst düzey becerileri ölçen bir sınavın & \multirow{3}{*}{ Ö12,Ö21 } & \multirow{3}{*}{2} \\
\hline & hazırlık aşamasının aşamalı ve & & \\
\hline & temelden başlayarak olması gerektiği & & \\
\hline & $\begin{array}{l}\text { Programda belirtilen hedeflerin üst } \\
\text { düzey becerileri sorgulamadan uzak }\end{array}$ & Ö14,Ö19,Ö20,Ö31 & 4 \\
\hline
\end{tabular}

Tablo 5'deki tema ve kodlardaki frekans yığılmaları Grafik 5'de yer almaktadır. 


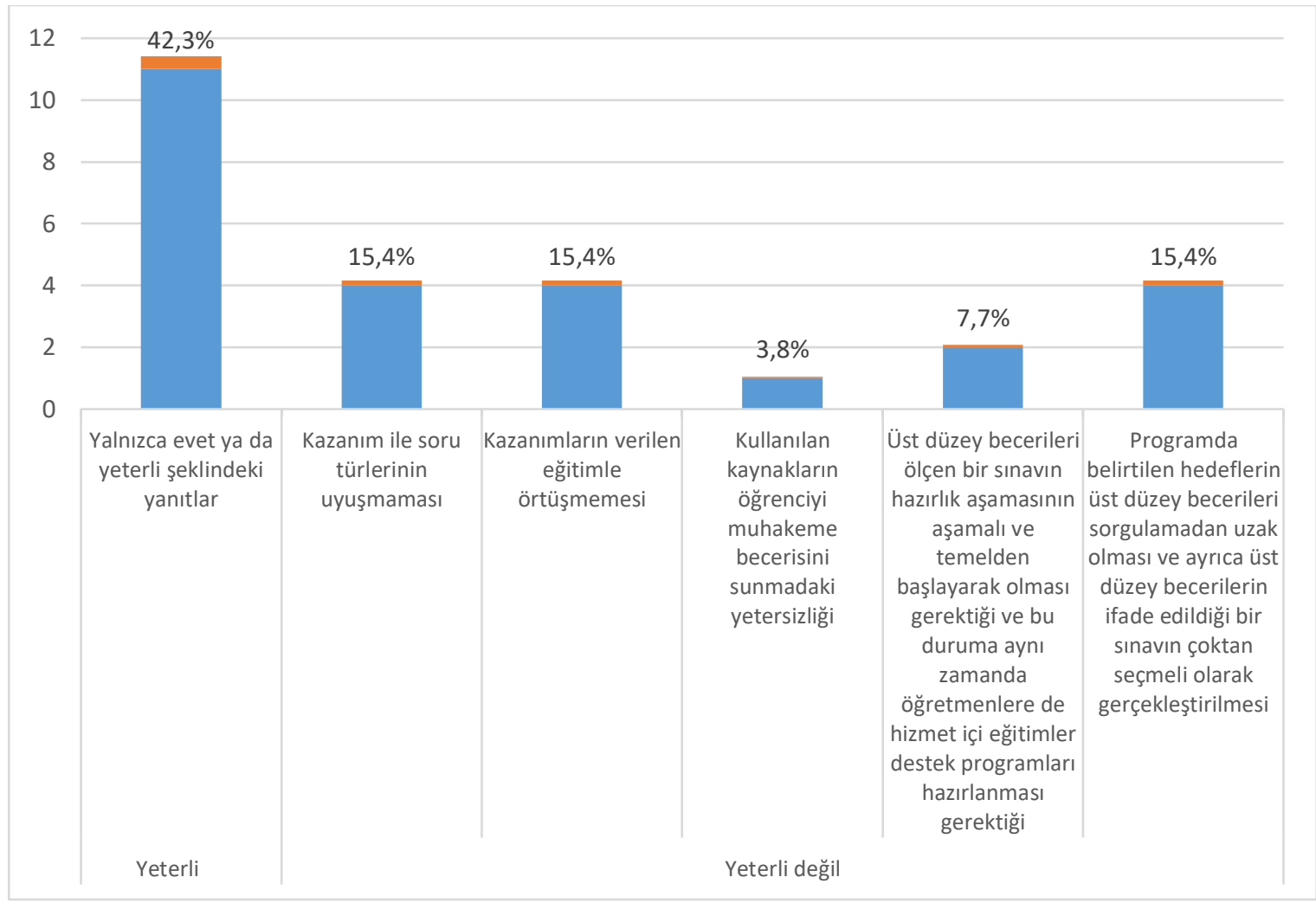

Grafik 5. Öğretmenlerin LGS'nin, ortaokul öğretim programında belirtilen ve geliştirmeyi hedeflediği temel becerileri (problem çözme, eleştirel düşünme, yaratıcı düşünme, karar verme, değişim ve sürekliliği anlama, sosyal katılım, akıl yürütme gibi) ölçmedeki yeterliliği hakkındaki görüşlerine ait bulgular

LGS'nin ortaokul öğretim programında hedeflenen temel becerileri ölçmede yeterliliğine ilişkin bazı birebir öğretmen yanıtları şöyledir:

Ö37: Okuduğunu anlama üzerine oluşturulan sorular ile asıl olanın test çözmek değil de, en başta Türkçeyi iyi ve hızlı okumak olduğunu tam olarak anlamaların sağlayacak yeterliliğe yavaş yavaş gelecektir umarım.

Ö12: Kesinlikle yanlış. Çünkü bu hedefe asama aşama geçilmeli. Yani sen 2 yll önce bilgi düzeyinde sorular sorarken, 2018 de öyle bir sistem getiriyorsun ki analiz sentez düzeyinde birden bir geçiş olmamalyydı. Yıllara göre üst düzey soruların sayısı artarak yapılabilirdi. 
Ö14: Önceki yıllara nazaran daha fazla ölçmeye dönük, ancak ifade edilen becerileri nihayetinde 4 seçenekli bir sinavla ölçmek bir çelişki. Zira sınavla tamamıyla ölçmek çok mümkün görünmüyor.

Ö21: Mantık-muhakeme, akl yürütme, okuduğunu anlama becerileri ön planda tutan bir sinav. Bu açıdan çok önemli. Ama öğrenciler, 5. sinıftan itibaren bu becerilerle yetiştirilmiyor. Son sene bu becerileri kazanmalart için yeterli değil

Ö27: Oluşması istenen becerileri ölçüyor aslında. Sikıntı, hedeflenen bu becerilerin mevcut programlarla istenen düzeyde elde edilememesi

5- Ortaokul öğretmenlerine göre, liselere geçiş sisteminde öğrencilerin evinin yakınında okula gidecek olması ve sınav mecburiyetinin olmamasının, öğrenci başarısına etkisine dair bulgular

Tablo 6. Uygulanan Sistemde Öğrencilerin Evinin Yakınında Okula Gidecek Olması ve Sınav Mecburiyetinin Olmamasının Öğrenci Başarısını Ne Düzeyde Etkilediğine Dair Öğretmen Görüşleri

\begin{tabular}{|c|c|c|c|}
\hline Tema & Kod & Katılımeılar & Frekans \\
\hline \multirow{5}{*}{ Etkiler } & $\begin{array}{l}\text { Güdülenme ve derse karşı ilgi } \\
\text { azalması }\end{array}$ & $\begin{array}{l}\text { Ö1,Ö4,Ö5,Ö10,Ö16,Ö19 } \\
\text {,Ö25 }\end{array}$ & 7 \\
\hline & $\begin{array}{l}\text { Öğrenciler aras1 } \\
\text { sinıflanmalara sebep olması }\end{array}$ & Ö34,Ö44 & 2 \\
\hline & Hedef kayb1 & Ö12,Ö35,Ö45,Ö46 & 4 \\
\hline & Akran etkilenmesi & Ö14 & 1 \\
\hline & $\begin{array}{lll}\text { Fırsat eşitsizliğine } & \text { sebep } \\
\text { olması } & & \\
\end{array}$ & Ö34 & 1 \\
\hline Etkilemez & Sınav güdüsü yüksek öğrenci & Ö2,Ö3,Ö44,Ö47 & 4 \\
\hline
\end{tabular}

Tablo 6'daki tema ve kodlardaki frekans yığılmaları Grafik 6'da yer almaktadır. 


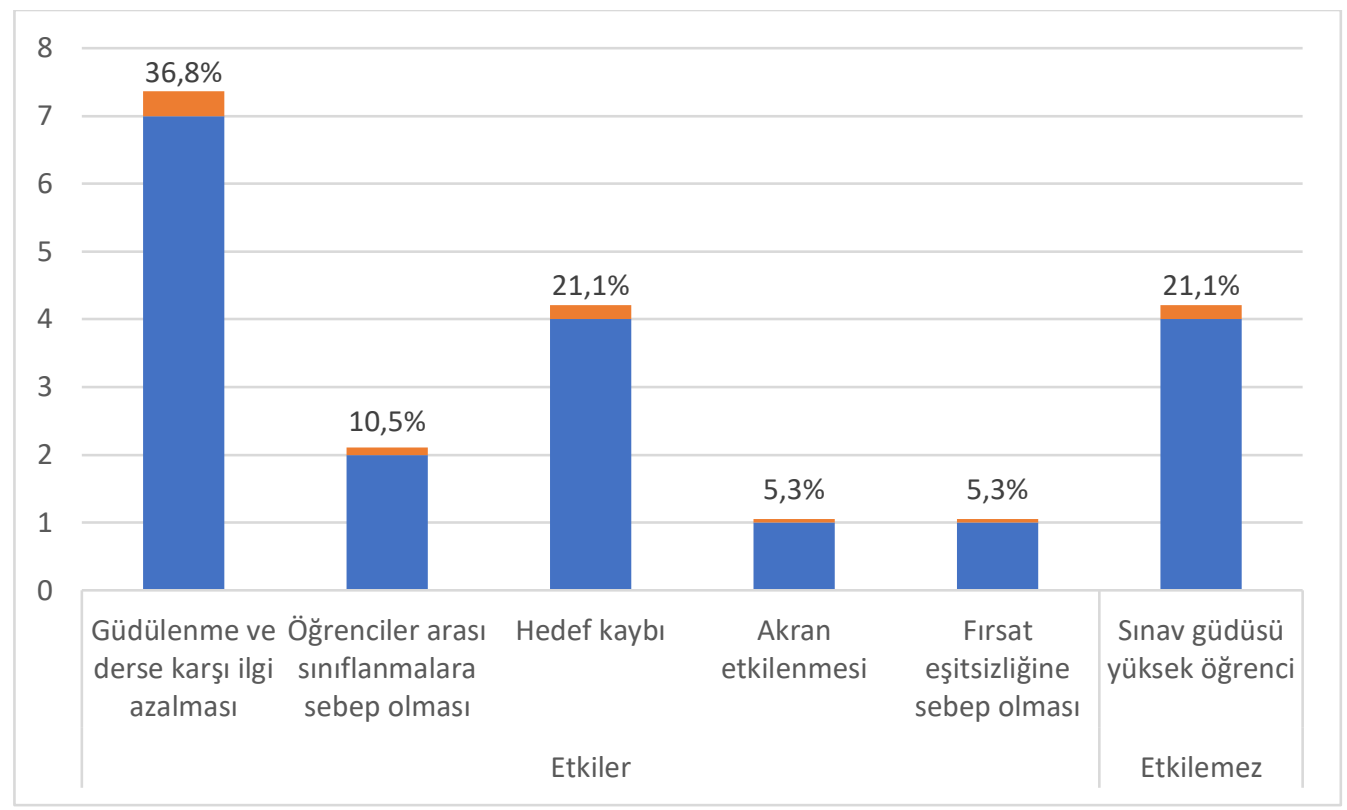

Grafik 6. Uygulanan sistemde öğrencilerin evinin yakınında okula gidecek olması ve sınav mecburiyetinin olmamasının öğrenci başarısını ne düzeyde etkilediğine dair öğretmen görüşlerine ait bulgular

Tablo 6’ya göre, öğretmenler, liselere geçiş sisteminde öğrencilerin evinin yakınında okula gidecek olması ve sınav mecburiyetinin olmamasının, öğrenci başarısını etkileyeceği yönünde görüş bildirmişlerdir (\%80). Bu durumu açıklar yanıtlarda, nitelikli okula kayıt hakk1 kazanamayacağını düşünen öğrencinin, motivasyonunun ve derse olan ilgisinin azalacağı $(\% 36,8)$, öğrencide hedef kaybı oluşacağı $(\% 10,5)$, akran etkilenmesinin ortaya çıkacağı $(\% 5,3)$ ve firsat eşitsizliğine yol açacağı $(\% 5,3)$ ifade edilmiştir. Etkilemez teması altında ise, öğrencinin evine yakın okula gidecek olmasının ve sınav mecburiyetinin olmamasının, sınav güdüsü yüksek olan öğrencinin başarısını etkilemeyeceği $(\% 21,1)$ ifade edilmiştir.

Bu durma ilişkin bazı birebir öğretmen yanıtları aşağıda yer almaktadır:

Ö31: Başarıyı düşürmektedir. İsteksiz olan öğrenci, dönemin başında ders çalışmayı birakmaktadir.

Ö38: Etkiliyor. Çocuklar nasılsa bir yere girerim ortalamayla diye düşünüp, bir garantisi olduğunu biliyor ve motivasyonu düşebiliyor. 
Ö45: Başarıyı değil, başarısızlı̆̆ı, hedefsizliği özendirdiği çok açık. Çünkü nitelikli okulların kontenjanları son derece düşük. Hiç bir şey yapmasan da bir okula girmek artık çok kolay. Bu şekilde okullar ve ögretmenler arasında da bir ayrım yapılmakta ve itibarsızlaştırılmakta.

Ö38: Etkiliyor. Her öğrencinin evinin yakınında donanımlı bir okul yok. Bu yüzden öğrenciler, boş vermişliğe düşebiliyor. Şanslı olanlar da, zaten okul yakınımızda deyip çalışmıyor.

Ö41: Evet. Ama sinavla nitelikli okullara girmeleri çok zor. Bunu bilmeleri, zaten kendilerini başarısız görmeleri için yeterli.

Diğer yandan, öğrencinin evinin yakınında okula gitmesi ve sınav mecburiyetinin olmamasının, öğrenciler arasında sınıflandırmalara sebep olacağı gibi, aynı zamanda, fırsat eşitsizliği de oluşturacağını ifade eden yanıtlar çok dikkate değerdir. Bu duruma ilişkin bazı birebir öğretmen yanıtları şöyledir:

Ö38: Etkiliyor. Her öğrencinin evinin yakınında donanımlı bir okul yok. Bu yüzden öğrenciler boş vermişliğe düşebiliyor. Şanslı olanlar da, zaten okul yakınımızda deyip çalışmıyor.

Ö2: Aslında bu tam olarak uygulanamıyor. Çünkü okulların adres alanı yerleşim yerinin en az yarısını kapsıyor. Bu durumda, okullar arasında, başarı ortalamasına göre sıralanmasına neden oluyor. Okumak isteyen öğrenci açısından motivasyonda değişikliğe sebep olmuyor.

\section{Sonuç Tartışma ve Öneriler}

Bu çalışmada, ortaokul öğretmenlerine göre, 2017-2018 eğitim öğretim yılında uygulamaya konulan ortaöğretim merkezi sınavı (LGS)'nın üstün ve sınırlı yönlerinin ortaya konulması amaçlanmıştır. Çalışma bulgularına göre, öğretmenler, 2018 yılında uygulamaya konulan merkezi yerleştirme sınavı (LGS)'nın sınırlı ve üstün yönleri olarak; soruların, temel bilgilerin yanı sıra, okuduğunu anlama becerisi, işlem yeteneği, analitik düşünebilme, mantıksal düşünüp muhakeme yapabilme, disiplinler arası aktarımda bulanabilme yeterlikleri gerektirdiğini belirtmişlerdir. $\mathrm{Bu}$ durumun, üst düzey yeterlilik gösterebilen başarılı öğrenciyi ön plana çıkarabilmesi açısından, sınavın diğer sınavlara kıyasla üstün yönü, fakat diğer yandan, soruların her öğrenciye hitap edemediğinin ise sınırlı yönü olduğunu belirtmişlerdir. Alan yazında, bu bulguları destekleyici çalışmalar yer almaktadır. Güler ve Ülger (2019), 2018 LGS sınav sorularının, TEOG sınav sorularından farklılaşarak, PISA'da sorulan sorulara benzer şekilde oluşturulduğunu 
belirtmektedirler. Yaprakgül (2019) çalışmasında, PISA ve TIMMS'de olduğu gibi, mantıksal düşünme yeteneği ile cevaplanacak sorulara, 2018 LGS’de önceki yıllarda yapılan sınavlara göre, daha fazla yer verildiğini ortaya koymuştur. Şıvkın, Aksoy ve Erdoğan (2020)'nın çalışma sonuçlarına göre, merkezi yerleştirme sınavında sorulan matematik soruları ile PISA'da sorulan matematik okuryazarlığı soruları arasında okuduğunu anlama, soruların günlük hayat problemleriyle ilişkilendirilmesi ve analiz sentez yapma becerisini ölçme açısından benzerlik bulunmaktadır.

Öğretmenlere göre, \%10’luk dilim içerisinde yer alarak, nitelikli okullarda öğrenim görmeye hak kazanan öğrencinin başarılı olduğu LGS'de, sınav heyecanı ve sınav kaygısı gibi sebeplerden ötürü sınava yenik düşen başarılı bir öğrencinin, nitelikli okulda öğrenim görememesi, sınavın ayırt ediciliğini olumsuz yönde etkilemektedir. Ayrıca, sınavın sayısal alanda oldukça zor sorular içermesinin, sözel alanda ise, soruların paragraf çözmeye yönelik olmasının ve bilginin öğrenilmesinden ziyade doğrudan yoruma açık hale getirilmesinin, sınavın ayırt ediciliğini düşürdüğü ifade edilmiştir. Benzer şekilde, Demir ve Yılmaz (2019), çalışmalarında, yalnızca \%10’luk kontenjan dilimindeki öğrencilerin nitelikli okullara gidebilmesini, hastalık, aşırı kaygı ve stres gibi sebeplerle, sınavda başarılı olamadığı için, öğrencilerin evlerine yakın okullara yerleştirilmeye mecbur tutulmasının olumsuzluk olarak ortaya koymuşlardır.

Çalışmanın bir diğer sonucuna göre, öğretmenler, LGS'nin içeriğinde yer alan soru türlerinin, kazanımların çok üzerinde olduğunu ve soruların müfredatla öğrenciye kazandırılmak istenen becerilerden daha üst düzey beceri gerektirdiğini belirtmişlerdir. Alan yazında, bu sonuçlar ile örtüşen çalışmalar yer almaktadır. Ekinci ve Bal (2019), LGS sınavı matematik sorularının uygulama düzeyinden başladığını ve üst düzey becerileri temsil eder nitelikte olduğunu belirtmiştir. Yine Erden (2020) çalışmasında, beceri temelli sorularla ders kazanımlarının tam olarak uyumlu olmadığını, soruların kazanım üstü, uzun, anlaşılırlığı güç içeriğe sahip olduklarını ve farklı nitelikteki becerileri ölçtüğünü ifade etmiştir. Kızkapan ve Nacaroğlu (2019) çalışmalarında, sınavda üst düzey düşünme becerileri gerektiren sorular yer alırken, ders kitaplarının öğrencileri bu soruları cevaplayacak şekilde hazırlamakta yetersiz olduğu sonucuna varmışlardır.

Bir diğer sonuca göre, öğretmenler, LGS'nin, ortaokul öğretim programında belirtilen ve geliştirmeyi hedeflediği temel becerileri -problem çözme, eleştirel düşünme, yaratıcı düşünme, 
karar verme, değişim ve sürekliliği anlama, sosyal katılım, akıl yürütme gibi- ölçmedeki yetersiz olduğu yönünde görüş bildirmişlerdir. Benzer biçimde, Erden (2020) çalışmasında, LGS'de yer alan soruların, Türkçe ve matematik dersleri öğretim programlarının kazanımlarıyla uyumlu olmadığını, Türkçe, matematik ve fen bilimleri derslerinin öğretim programları ile ders kitaplarının, beceri temelli sorularla ilgili etkili bir rehberlik sağlama konusunda yeterli olmadığını ortaya koymuştur

Çalışmanın bir başka sonucuna göre, öğretmeler, liselere geçiş sisteminde öğrencilerin evinin yakınında okula gidecek olması ve sınav mecburiyetinin olmamasının, öğrenci başarısını etkileyeceği yönünde görüş bildirmişlerdir. Demir ve Yılmaz (2019), çalışmalarında, adrese dayalı kayıt sisteminin olumsuz sonuç doğurabileceğini ortaya koymuşlardır. Gür, Çelik ve Coşkun (2013) ise, çalışmalarında, öğrencilerin evinin yakınında okula gidecek olmasının, sınavın öğrenci üzerindeki baskını azaltacağını ve bu sebeple olumlu olacağını, fakat bu sistemin çevresel faktörler nedeniyle, toplumsal eşitsizliği artıran bir sistem olarak algılanmasına neden olabileceğini belirtmişlerdir. Altınkurt ve Yılmaz (2011)'da, çalışmalarında, bu sistem ile eğitimde firsat eşitliliğinin ihlal edildiğini, mevcut kademede öğrenme firsatı az olan kesimle, bu firsatı daha fazla olan kesimin bir arada değerlendirilmesinin, hali hazırda var olan eşitsizliği daha da artıracağını belirtmişlerdir.

Çalışma sonuçlarına dayalı ve gelecek araştırmalara yönelik öneriler şunlar olabilir: 1Öğretmenlere, LGS sınavının yapısı, içeriği, soruların düzeyi ve kazanımlar ile ilişkisi gibi konularda bilgilendirme eğitimleri verilmelidir. 2- Özelikle 8. Sınıf öğretim programı, ders kitapları içerikleri, öğrenme-öğretme süreçleri, LGS sınavı ile ilişikli biçimde yenilenmelidir. 3Nitelikli-niteliksiz okulun ölçütleri ve Türkiye'deki mevcut duruma dönük araştırmalar yapılmalıdır. 4- LGS sınavına ilişkin benzer çalışmalar, veli, öğrenci ve okul yöneticilerine dönük yapılmalidır.

\section{Kaynaklar}

Atila, M. E. ve Özeken, Ö. F. (2015). Temel eğitimden ortaöğretime geçiş sınavı: Fen bilimleri öğretmenleri ne düşünüyor? On Dokuz Mayıs Üniversitesi Eğitim Fakültesi Dergisi, 34(1), $124-140$ 
Büyüköztürk, Ş. (2016). Sınavlar üzerine düşünceler. Kalem Eğitim ve İnsan Bilimleri Dergisi, $6(2), 345-356$

Cüceloğlu, D. ve Erdoğan, İ. (2018). Öğretmen olmak: bir can'a dokunmak. Final Kültür Sanat Yayınlar1.

Çepni, S., Özsevgec, T. ve Gökdere, M. (2003). Bilişsel gelişim ve formal operasyon dönem özelliklerine göre ÖSS fizik ve lise fizik sorularının incelenmesi. Milli Ĕ̆itim Dergisi, 157, 30-39

Demir, S. B. ve Yılmaz, T. A. (2019). En iyisi bu mu? Türkiye'de yeni ortaöğretime geçiş politikasının velilerin görüşlerine göre değerlendirilmesi. Bolu Abant İzzet Baysal Üniversitesi Eğitim Fakültesi Dergisi, 19 (1), 164-183

Demirel, Ö. (2010). Eğitimde program geliştirme. Ankara: Pegem Akademi.

Ekinci, O. ve Bal, A. P. (2019). 2018 yılı liseye geçiş sınavı (LGS) matematik sorularının öğrenme alanları ve yenilenmiş Bloom taksonomisi bağlamında değerlendirilmesi. Anemon Muş Alparslan Üniversitesi Sosyal Bilimler Dergisi, 7(3), 1-1

Erden, B. (2020). Türkçe, matematik ve fen bilimleri dersi beceri temelli sorularına ilişkin öğretmen görüşleri. Academia Ĕ̆itim Araştırmaları Dergisi, 5(2), 270-292

Ertürk, S. (2017). Eğitimde program geliştirme. Ankara: Edge Akademi.

Görmez, M. ve Coşkun, İ. (2015). 1. y1lında temel eğitimden ortaöğretime geçiş reformunun değerlendirilmesi. SETA/Siyaset, Ekonomi ve Toplum Araştırmaları Vakfı, 114, 1-21. 14 Nisan 2021 tarihinde http://file.setav.org/Files/Pdf/20150115172839_1.-yilinda-temelegitimden-ortaogretime-gecisreformunun-degerlendirilmesi-pdf.pdf adresinden alınmıştır.

Gür B., S., Çelik Z. ve Coşkun İ. (2013). Türkiye'de ortaöğretimin geleceği: Hiyerarşi mi, eşitlik mi? SETA | Siyaset, Ekonomi ve Toplum Araştırmaları Vakfı. Sayı:69, 1-28. 14 Nisan 2021 tarihinde http://file.setav.org/Files/Pdf/20130802120003_ortaogretim_analiz2.pdf adresinden alınmıştır.

Kızkapan, O. ve Nacaroğlu, O. (2019). Fen bilimleri öğretmenlerinin merkezi sınavlara (LGS) ilişkin görüşleri. Nevşehir Hacı Bektaş Veli Üniversitesi Dergisi, 9(2). 701-719 
Journal of Social Research and Behavioral Sciences, Volume: 7 Issue: 13 Year: 2021

Milli Eğitim Bakanlığı (MEB). (2018a). Millî Ĕgitim Bakanlığı ortaöğretim kurumları yönetmeliğinde değisşiklik yapılmasina dair yönetmelik. https://www.resmigazete.gov.tr/eskiler/2018//20180214 adresinden 28 Mart 2021 tarihinde erişilmiştir.

Milli Eğitim Bakanlığı (MEB). (2018b). PISA 2018 Türkiye ön raporu. Ĕgitim analiz ve değerlendirme raporları serisi. No:10, Aralık 2019

Özdaş, F. (2019). Merkezi yerleştirme sınav sistemine ilişkin öğretmen ve öğrenci görüşlerinin değerlendirilmesi. Mukaddime, 10(2), 688-707

Özkan, E. ve Karataş, İ. H. (2016). Ortaöğretime geçiş sisteminde yapılan değişikliklere ilişkin öğrenci görüşlerinin analizi. Eğitim ve Öğretim Araştırmaları Dergisi, 5(1), 214-223. Erişim adresi: http://www.jret.org/FileUpload/ks281142/File/24a._erkan_ozkan_.pdf

Şıvkın, S. Aksoy, C. V. ve Erdoğan, G.D. (2020). LGS' de sorulan PISA tarzı matematik sorularını doğru cevaplama ile okuduğunu anlama arasındaki ilişkinin öğretmen görüşlerine göre değerlendirilmesi. Sakarya Üniversitesi Eğitim Fakültesi Dergisi, 20(2), 148-159.

Sönmez. V. (2007) Program Geliştirmede Öğretmen El Kitabı. Ankara: Anı Yayıncılık.

Turgut, M. F. ve Baykul, Y. (2013). Eğitimde ölçme ve değerlendirme, Ankara: Pegem Akademi Yayıncilik.

Turgut, M. F. ve Baykul, Y. (2014). Eğitimde ölçme ve değerlendirme, Ankara: Pegem Akademi Yayıncilik.

Yaprakgül, S. (2019). Ortaöğretime geçiş sinavları (teog, lgs) ile pısa, tımss sinavları matematik sorularının matematiksel ve matematik eğitimi değerleri açısından incelenmesi (Yayımlanmamış Yüksek Lisans Tezi). Erzincan Binali Yıldırım Üniversitesi Fen Bilimleri Enstitüsü, Erzincan.

Yıldırım, A. ve Şimşek, H. (2013). Sosyal bilimlerde nitel araştırma yöntemleri. Ankara: Seçkin Yayıncilik.

Yılmaz, K. \& Altınkurt, Y. (2011). Öğretmen adaylarının eleştirel pedagoji ile ilgili görüşleri. Ahi Evran Üniversitesi Kırşehir Ĕgitim Fakültesi Dergisi, 12(3), 195-213. 